\title{
Nutritional Analysis of Locally Preferred Fodder Trees of Middle Hills of Nepal: A Case Study from Hemja VDC, Kaski District
}

\author{
Sunita Dhungana, Hari P. Tripathee, Lila Puri, Yajna P. Timilsina and Krishna P. Devkota \\ Institute of Forestry \\ Tribhuvan University, Pokhara Campus \\ P. O. Box: 43, Pokhara, Kaski \\ e-mail:devkotapd@yahoo.com
}

\begin{abstract}
The study on nutritional value of locally preferred fodder trees in the farmland of middle hills of Nepal was conducted in Hemja VDC of Kaski district. Primary information on distribution and frequency of fodder trees was obtained through key informants survey, group discussion and observation of the study area. The preference ranking of ten most abundant fodder trees was done on the basis of palatability, propagation easiness, growth rate and competition with agricultural crops. The nutritional value of fodder species was analyzed and compared with the farmers' preference ranking to examine association among them. The analysis correspond farmers' preference of fodder tree species to their nutritional values. The study revealed that Ficus subinisa was the dominant fodder tree however, the Artocarpus lakoocha was highly preferred trees for its palatability and nourishing values. Nutritional analysis of ten preferred fodder species with respect to moisture, ash, crude protein, crude fat, crude fiber and carbohydrate was carried out. The crude protein varied from 15-29\%, in which, A. lakoocha to contained the highest amount of crude protein. Similarly, F. lacor contained highest crude fiber (42.07\%), and Machilus odoratissima yielded highest amount of carbohydrate (21.92\%).
\end{abstract}

Key words: crude protein, carbohydrate, nutritional analysis, palatability, preferred species

\section{Introduction}

Nepal is a hilly agricultural country where mixed croplivestock farming system is predominated since centuries (Tulachan \& Neupane 1999). Livestock has remained as an indispensable part of the traditional agricultural systems in hilly regions of Nepal (Devkota \& Rerkasem 1994). It has played a major role in generating cash income through the production of milk, butter, meat, egg, hides, skin, wool, manure, and draught. Livestock farming has been considered as one of the fastest growing agricultural sectors of Nepal (APP 1995). However, the productivity of these native animals is very low. The major reason of low productivity of the livestock is insufficient and low quality feeds and fodders especially during the dry season (Tulachan \& Neupane 1999, Keftara 1994, Pandey et al. 1998). Hence, fodder trees from forests, pastures and agricultural lands play major role to meet the defficiency of animal feeds in rural areas.
For the purpose of this paper, fodder trees can be defined as trees bearing leaves and tender twigs palatable to cattle and other animals. In Nepal, this is commonly known as dale ghans, a term being used for leaves coming from trees, shrubs, branches, woody vines and herbaceous climbers. Farmers in Nepal have a considerable knowledge of fodder trees and their nutritional qualities (Mahato \& Subb 1988). The nutritional values of fodders differ according to species and season of the growth and, therefore, farmers prefer different species for different seasons, and animals to be fed. The traditional and experience-based choice of fodders species by farmers reflects their knowledge on nutritional values, cultivation easiness and seasonal variability of growth in local environments.

Fodder trees are indispensable resources of animal feed in Nepal mainly in the dry seasons (Rana et al. 1999). However, present level of fodder tree production 
is meeting only about $30 \%$ of the domestic needs (Miller 1993). In general, fodder tree leaves contain higher protein and calcium compared to grasses and straws (Rana et al. 1999) and a wide range of fodder trees have been utilized by the ruminants as a major source of feeding materials (Pandey \& Osti 1995). This emphasizes the needs of promoting and developing ranges of fodder trees as important source of feeding materials especially for ruminants in mid hills of Nepal. Fodder trees provide nearly $40 \%$ of the total annual fodder requirement of the ruminants in the hills (Malla 2004).

Nutrient contents are fairly high in all fodder tree species however, their amount differs noticeably from one species to another (Subba 1998, Amatya et al. 1997, Mahato \& Subba 1998). Differences in nutrient contents in an individual species also occur with the change in season (Malla 2004). About one hundred tree species varying greatly in their quality, palatability and preferences to the farmers are being used for this purpose (Pandey 1982). Of them, $B$. purpurea, F. nimoralis, A. lakoocha, F. subinisa, F. calvata, are valued by the farmers as highly nutritive fodders that increase milk and fat (Thapa 1994). They have crude protein up to $16 \%$ and are relatively low in tannins. Many fodder species are popular for Terai, Mid-hill and Himalayas. People have more indigenous knowledge towards these fodder tree but not much idea about their nutritive values.

Although nutritional value of some fodder tree species has been widely studied, there is still a lack of study in such values on many common fodder species around the country. More studies are focused on crude protein rather than on others such as carbohydrate, crude fiber, etc. So, this research is applied for evaluating different nutritional values of fodder tree species which help farmers to select useful species. Likewise, farmers will also be aware about the nutritional value of fodder tree species.

\section{Methodology}

This study was carried out in Hemja VDC of Kaski district, a mid hill area of central Nepal. The research was conducted from April to September, 2010. The study was undertaken in two stages: i) ranking of most abundant fodder tree of the study area and ii) nutrient analysis of the preferred species in the laboratory. List of fodder trees grown in the study area was obtained through field observation, participatory discussion with lead farmers, tree owners and other key informants. The most abundant species were listed to be used for further ranking exercises. Out of 1800 households of the VDC, 180 (10\%) were randomly selected for i) assessment of fodder trees owned and used by the farmers and ii) preference ranking of fodder trees under different criteria. The nutrient analysis of preferred and high ranked species was undertaken in the laboratory.

For ranking of the fodder trees, criteria for preferring fodder species were developed by asking farmers to suggest important qualities of fodder of their choice. Out of several criteria provided, the farmers selected four (criteria) to be important and determinant for the preference of particular species over other. The criteria used were: i) palatability, ii) growth rates, iii) propagation easiness and iv) competition with agricultural crops of the fodder species. List of ten most abundant species were taken to respondents for ranking them from most preferred as 'I' to least preferred as 'IX' for each criterion. Field note was maintained for further explanation of fodder qualities during the formal and informal discussion in villages.

For nutritional analysis, foliage samples of ten most preferred species were collected. Among top ten most preferred trees, sample were taken from ten trees for each species within the study site and made them composite and used the required samples for the lab test. Each sample was properly labeled, packed in plastic bags and taken to the laboratory. The green samples were air-dried, crushed with plant grinder and $100 \mathrm{~g}$ of each sample was used for nutritional analysis. The Samples were collected during July-August of the study year to get matured foliage samples from the tree. The analysis was carried out in the medicinal and Aromatic Plants Research Laboratory of the Institute of Forestry and in LI-BIRD Pokhara.

\section{Nutritional analysis}

The detailed nutritional analysis protocol has also been published by Magrati et al. 2011. A brief procedure is described below. All the nutritional values were reported in percentage (AOAC 1990). 


\section{Determination of moisture}

One gram of each sample was taken in a petri-dish and placed in an oven at $100^{\circ} \mathrm{C}$ for four hours. It was then cooled in desiccators and weighed. The samples were heated again in the oven for another two hours and the process was repeated, till a constant weight obtained. The moisture content was calculated by using the following formula. This process was repeated twice for getting precise data.

Moisture $(\%)=\underline{\text { Weight of fresh sample }- \text { Weight of dried sample }} \times 100$ Weight of sample

\section{Determination of ash}

One gram dried sample of each species was taken in a crucible and charred over a low flame and kept in a muffle furnace set at $550{ }^{\circ} \mathrm{C}$ until white ash was obtained. The ash was moistened with water, dried on steam and then on hot plate. The crucible was again placed in the muffle furnace at $550^{\circ} \mathrm{C}$, till a constant weight was obtained. The percent ash was calculated as:

$$
\text { Ash }(\%)=\frac{\text { Weight of sample after ash }}{\text { Weight of sample }} \times 100
$$

\section{Determination of crude fat}

The dried sample of each species was taken and crushed. Two gram of the sample was taken in a paper thimble and connected to a soxhlet extractor. Then 300 $\mathrm{ml}$ of petroleum ether was poured on the flask and refluxed for 12 hours with a heating mantle. Crude fat was extracted in a flask. The flask was cooled in a desiccators and the weight was taken. Crude fat was determined by using the formula:

Crude fat $(\%)=$ Weight of flask with fat - Weight of empty flask $\times 100$ Weight of original sample

\section{Determination of crude fiber}

One gram of the defatted plant material of each species were taken in beakers and boiled in $200 \mathrm{ml}$ of $1.25 \%$ sulphuric acid for 30 minutes. The content was then filtered and washed with distilled water to neutralize the content. The content was transferred again to the beaker and boiled in $200 \mathrm{ml}$ of $1.25 \%$ sodium hydroxide for 30 minutes. They were again filtered and washed with distilled water for neutralization. A Gooch crucible was prepared with an asbestos mat and the contents of the beakers were placed on the mat and washed with 15 $\mathrm{ml}$ of ethyl alcohol. The crucible was dried in an oven at $110^{\circ} \mathrm{C}$ to a constant weight. The crucible having crude fiber was cooled and weighed (W1).

The content of the crucibles were ignited over a low flame until charred and then kept in a muffle furnace at $550^{\circ} \mathrm{C}$ and weighed (W2).

The Percentage fiber was determined by the following formula:

$$
\text { Crude fiber }(\%)=\frac{\mathrm{W} 1-\mathrm{W} 2}{\text { Weight of sample }} \times 100
$$

Determination of protein by micro Kjeldahl's method Proteins were analyzed by Micro Kjeldahl's method described by Pearson (1976), involving digestion, distillation and titration of the samples.

\section{Digestion}

$0.5 \mathrm{~g}$ of dried plant material of each species was taken in the digestion flask. To this, $1.0 \mathrm{~g}$ of the digestion mixture (copper sulphate and potassium sulphate, 1:18) and $7 \mathrm{ml}$ of concentrated sulphuric acid was added. The solution was heated until it became clear and frothing ceased. It was then boiled gently for another 2 hours and then it was cooled down. This digested material was mixed with $30 \mathrm{ml}$ of water with constant mixing. The digest was transferred to $100 \mathrm{ml}$ volumetric flask and necessary amount of water was added up to the mark of the flask.

\section{Distillation}

The Parnas Wagner distillation assembly was arranged. $25 \mathrm{ml}$ of $4 \%$ boric acid was taken and 1 drop of methyl red indicator was added, by which pink color could be observed. Then $5 \mathrm{ml}$ of the digest was transferred to the distillation assembly and $10 \mathrm{ml}$ of $32 \%$ sodium hydroxide solution was added on it. The distillation was completed in 10 minutes indicating the change of color of boric acid to yellow due to the formation of ammonium borate.

\section{Titration}

The boric acid having trapped ammonia was titrated with $0.1 \mathrm{~N}$ hydrochloric acid, the colour of boric acid having ammonia changed again to pink. The percent protein was calculated by the formula:

Protein $(\%)=\underline{1.4 \times 6.25 \times 0.1 \mathrm{~N} \mathrm{HCl} \times \text { Vol (used) }}$ Weight of sample 
Where;

$\begin{aligned} 1.4= & \text { Weight of nitrogen expressed in gram in the } \\ & \text { formula } \\ 6.25= & \text { Protein factor }\end{aligned}$

\section{Determination of carbohydrate}

Carbohydrate was determined by difference, using following formula:

Carbohydrate (\%) = 100 - (moisture + crude fat + ash + protein)

The results of nutrient analysis was examined and correlated with farmers preference to analyze any causal relationship or association between preference ranks and the nutrient contents of fodder trees. Spearman's rank correlation and its significance by ttest was employed to analyze association between crude protein content with palatability preference of the fodder tree at $5 \%$ level of significance.

\section{Results and Discussion \\ Preference of fodder trees}

The result of farmers' preference status of ten most abundant fodder trees has been presented in Table 1. The study revealed that majority of the farmers agreed with $A$. lakoocha as being a highly preferred species and $F$. hispida as the lowest preferred species for palatability criteria. However, F. subinisa was found to be highly preferred species for its propagation easiness, fast growth and less competitive with agricultural crops. B. hanila was found very fast growing tree species of the study area. Other species like F. roxburghii, F. glaberrima and B. hainla were not preferred for their competition with agricultural crops.

Table 1. Most preferred fodder tree species by farmers in the study area

\begin{tabular}{|c|c|c|c|c|}
\hline \multirow[t]{2}{*}{ Species } & \multicolumn{4}{|c|}{ Criteria used for preference ranking } \\
\hline & Palatability & Propagation easiness & Growth rate & $\begin{array}{l}\text { Competition with } \\
\text { agricultural crops }\end{array}$ \\
\hline A. lakoocha (Badhar) & I & IV & $\mathrm{V}$ & II \\
\hline F. subinisa (Bedulo) & II & I & I & II \\
\hline F. roxburghii (Nimaro) & III & VI & II & IX \\
\hline F. semicordata (Khanayo) & III & $\mathrm{V}$ & $\mathrm{V}$ & VIII \\
\hline L. monopetala (Kutmiro) & IV & IV & II & III \\
\hline F. lacor (Kavro) & V & V & IV & IV \\
\hline M. odoratissima (Kaulo) & VI & III & III & VII \\
\hline F. glaberrima (Pakhuri) & VI & IV & II & IX \\
\hline B. hainla (Chuletro) & $\mathrm{V}$ & II & $\mathrm{I}$ & IX \\
\hline F. hispida (Tote) & VI & IV & $\mathrm{V}$ & VII \\
\hline
\end{tabular}

Note: $\mathrm{I}=$ Most preferred, IX = Least preferred

In the study area, it was found that $F$. subinisa was one of the most widely distributed species, mainly grown on the homestead, farmland, and bunds, edge of farmland and grassland. Majority of the farmers agreed that $A$. lakoocha was highly preferred species. However, farmer argued that this species was the most preferred species and they wanted to expand it as compared to $F$. subinisa which is widely distributed fodder of that site. They also reported that A. lakoocha contained high nutrient value, which is good for lactating animals. This fodder tree increases milk and fat production together with rapid growth, weight gain and good health of livestock. Farmers felt that $F$. roxboughii and $F$. semicordata were rough, which decrease milk production of the livestock. According to farmers, rough fodders like F. roxboughii, $L$. monopetala and $F$. hispid are generally harvested before maturity of their foliage to avoid their roughness for animals. Likewise, F. glaberrima, M. odoratissima, $B$. hanila and F. lacor were considered just for the survival of livestock and not for supply of nutrition.

\section{Nutritional analysis}

Nutrient values of the sampled foliages, which were collected from the study plots have been displayed with their marked variations in their crude protein (CP), crude fiber (CF), crude fat (CF) and carbohydrate in Table 2. The CP contents in these species varied from $15 \%$ to $29 \%$ with A. lakoocha containing the highest CP of $28.64 \%$, while $M$. odoratissima having the lowest CP of $15.54 \%$. CF content was high in B. hanila (3.22\%) and low in F. semicordata (1\%). Similarly, CF is high in F. lacor (42.07\%) and low in F. hispida (23.03\%), and carbohydrate content is high in M. odoratissima 
Sunita Dhungana et al./Nutritional analysis of locally........

(21.92\%) and low in F. hispida (0.34\%). Similar variations are also reported by other research groups
(Rana et al. 1999 Brandis, 1978, Malla 2004, Kayastha et al. 1998 and Pandey et al. 2003).

Table 2. Nutritional values of ten preferred fodder tree species

\begin{tabular}{|c|c|c|c|c|c|c|c|}
\hline S.N. & Species & Moisture (\%) & Ash (\%) & $\begin{array}{l}\text { Crude } \\
\text { Protein } \\
(\%)\end{array}$ & $\begin{array}{l}\text { Crude Fat } \\
(\%)\end{array}$ & $\begin{array}{l}\text { Crude Fiber } \\
(\%)\end{array}$ & Carbohydrate (\%) \\
\hline 1 & A. lakoocha & 61.0 & 8.0 & 28.64 & 1.52 & 26.31 & 0.84 \\
\hline 2 & F. subinisa & 59.8 & 11.5 & 24.88 & 1.84 & 30.07 & 1.98 \\
\hline 3 & F. roxburghii & 66.4 & 11.5 & 18.13 & 2.34 & 26.31 & 1.63 \\
\hline 4 & F. semicordata & 64.0 & 12.5 & 19.70 & 1.00 & 24.77 & 2.80 \\
\hline 5 & L. monopetala & 66.0 & 5.0 & 26.70 & 1.14 & 30.72 & 1.16 \\
\hline 6 & F. lacor & 67.1 & 4.0 & 17.61 & 1.91 & 42.07 & 9.38 \\
\hline 7 & M. odoratissima & 54.2 & 5.5 & 15.54 & 2.84 & 41.39 & 21.92 \\
\hline 8 & F. glaberrima & 66.6 & 14.0 & 17.11 & 1.24 & 27.40 & 1.05 \\
\hline 9 & B. hainla & 61.3 & 8.5 & 25.16 & 3.22 & 26.95 & 1.82 \\
\hline 10 & F. hispida & 59.0 & 17.5 & 21.11 & 2.05 & 23.03 & 0.34 \\
\hline
\end{tabular}

In this study, the CP content of A. lakoocha was found to be higher (28.64\%) than the reported value of $13.17 \%$ by Rana et al. (1999) and $16.00 \%$ by Brandis (1978). Likewise, CP content in F. subinisa (24.88\%) was found to be consistent with the reported data by Brandis (1978), Malla (2004), Kayastha et al. (1998) and Pandey et al. (2003). The CP content of F. roxburghii was observed to be $18.13 \%$, which was also consistent with the data reported by Malla (2004), but was higher (12.13\%) than the value reported by Singh (1982). Similarly, CP content of F. semicordata (19.7\%) was found to be lower than the reported value of $24.27 \%$ by Pandey et al. (2003). Similarly, CP content of $L$. monopetala (26.7\%) was found to be higher than the values of $21.34 \%, 17.19 \%$ and $14.17 \%$ respectively, reported by Pandey et al. (2003), Rana (1999) and Jackson (1994). CP content of F. lacor (17.61\%) was less than the reported value of $22.03 \%$ by Pandey et al. (2003). CP content of F. glaberrima (17.11\%) was found to be similar to the value reported by Brandis (1978) and Pandey et al. (2003). Similarly, CP content of $B$. hainla (25.16\%) was higher than reported by Kayastha et al. (1998) and Brandis (1978). CP content of F. hispida (21.11\%) was higher than value reported by Kayastha et al. (1998). Literature evidences on CF of F. subinisa (32.23\%) reported by Pandey et al. (2003) was almost similar (30.07\%) to present study. Likewise, CF content of L. monopetala (47.15\%) reported by Pandey et al. (2003) was higher than this study (30.72\%). CF content of F. semicordata (36.94\%) reported by Pandey et al. (2003) was also higher than our result (24.77\%). The CF reported for B. hainla (32.26\%) by Pandey et al. (2003) was also higher than our result (26.95\%). The overall study and comparison with the literature indicated that the nutrient analysis was found to be within the ranges of other studies. But, the marked differences from other reported values could be associated with several attributes such as season and maturity stage of the foliage used for the analysis and the climatic conditions of the study sites compared to other studies.

The overall study indicated that fodder trees are important source of protein and other dietary supplements for livestock. The relation between proteins versus palatability is also compared. For this analysis, the crude protein value from the laboratory test and preference ranking data from the farmers were taken. It was found that there was association between farmers' preference for palatability and crude protein contents of the fodders. A. lakkoocha highly preferred by farmers was also found to have higher content of CF. It revealed farmers' experiences, subjective judgement and indigenous knowledge for fodder preferences can be constituent with its nutrient contents and are able to select high quality fodder for their livestock.

Farmers' preference ranking of different fodder trees was found to be associated with nutrient contents of the foliage from laboratory tests. The fodder trees were ranked based on four criteria: palatability, propagation esiness, growth rate and competition with agricultural crops. The highly preferred species were found to have high nutrient contents as shown by lab test. Farmers used their conscience to select species and harvesting season for particular species. Farmers value fodders that can have better nourishing quality for livestock. Due to this, despite the slow growth rate, farmers preferred A. lakoocha for its high nutritious value. 
Likewise, F. subnisa was highly preferred species based on ease on propagation and fast growth. Hence, A. lakoocha and F. subinisa were highly preferred species based on competitive ability with agricultural crop because these two species has no shading and harmful effect for their agricultural crop.

\section{Acknowledgements}

The Community Based Natural Forest and Tree Management in the Himalayas (ComForM) project is highly acknowledged for providing financial support for this study. We would also like to thanks the local people of Hemja VDC, Kaski district for providing useful information and all possible cooperation during our field study. Nutritional analyses were done in the Medicinal and Aromatic Plants Research Laboratory of Institute of Forestry, Pokhara which was established with the funding support of Alexander von Humboldt Foundation, Germany.

\section{References}

Agriculture Perspective Plan. 1995. National Planning Commission, Agriculture Project Service Centre, Government of Nepal, Kathmandu.

Amatya, S.M., S.P. Dhoubdhel and P.M. Pradhan. 1997. Monthly variation in nutrient contents in four fodder trees commonly grown in Nepal. Banko Jankari 7: 28-32.

Association of Official Analytical Chemists (AOAC). 1990. Official Methods of Analysis. $15^{\text {th }} \mathrm{Ed}$. Washington, DC, USA.

Brandis. D. 1978. Indian trees. Bishen Singh Mahendra Pal Singh. Dehradun, India.

Devkota, N.R. and B. Rerkesem. 1994. System understanding and analysis of agricultural practices in crop livestock integrated farming system of Chitwan, Nepal. Journal of Tribhuvan University 17:29-40.

Jackson, J.K. 1994. Manual of afforestation in Nepal. Forest Research and Survey Centre, Vol. I and II, $2^{\text {nd }}$ Ed., Kathmandu, Nepal.

Kayastha, B.P., M.H. Khan, S.N. Adhikari, R.A. Khan K.R. Tiwari and K.M. Shrestha. 1998. Dynamics of fodder trees in the middle hills of Nepal. In: Proceedings of International Seminar in Sustainable Forest Management. IOF/ITTO (31 August - 2 September, 1998), Pokhara, Nepal.

Keftara, D. 1994. Integration of livestock and crop production. Training notes for sixth Hohenheim legume course "Legumes in cropping system of the tropics and subtropics”, Tropical centre, Hohenheim University, Germany, May 30-June 24.
Magrati, T.P., K.P. Devkota and H.P. Tripathee. 2011. Nutritional analysis of Morchella conica and its role on rural livelihood. Nepal Journal of Science and Technology 12:119-126.

Mahato, S.N. and D.B. Subba. 1988. Nutritional evaluation of fodders at Pakhribas Agricultural Centre, Dhankuta. In the second meeting of the working Group of Fodder Trees, Forest Fodder and Leaf Litter, Ed. Robinson, P.J. FRIC, Forest Research and Survey Centre Babarmahal, Kathmandu, OccasionalPaper 2/88, 2022pp.

Mahato, S.N. and D.B. Subba. 1998. Chemical Composition and Nutritive Values of Feeds of East Nepal Pakribas Agricultural Centre, Dhankuta, Nepal.

Malla, M.B. 2004. Chemical composition and feed value of fodder trees from Palpa District, Nepal. Banko Jankari 14:27-30.

Miller, D.J. 1993. Rangeland in northern Nepal: Balancing livestock development and environmental conservation USAID, Kathmandu, Nepal.

Pandey, K.K. 1982. Fodder trees and tree fodder in Nepal. Swiss Development Cooperation and Swiss Federal Institute of Forestry Research, Switzerland.

Panday, S.B., and M.R. Tiwari 2003. Fodders resources and pastoral system in Nepal. In: Proceedings of the 5th meeting of the temperate Asia pasture \& Fodder Network, Bhutan.

Pandey, S.B., R.C. Khanal and S.K. Khanal. 1998. Effect of feeding urea- molasses-mineral block (UMMB) on the performance of lactating cross diary cows. In: Technical Report. Nepal Agricultural Research Council, Animal Nutration Division, Khumaltar, Lalitpur Nepal, 3-10 pp.

Pandey, S.B. and N.P. Osti. 1995. Chemical composition of different varieties of fodder trees. Nepalese journal of Animal Science 1:17-27.

Pearson, D. 1976. The chemical analysis of foods. 7th Ed., Churchill Livingstone, London, 7-11 pp.

Rana, R.S., F. Yano, S.K. Khanal and S.B. Pandey. 1999. Crude protein and mineral content of some major fodder trees of Nepal. Lumle Seminar paper No. 99/13, Lumle Agriculture Research Center, Nepal.

Singh, R.V. 1982. Fodder trees of India. Oxford and IBH Publishing Co., New Delhi, India.

Thapa, B. 1994. Farmers' ecological konwledge about the management and use of farmland tree fodder resources in the Mid-Hills of Eastern Nepal. Postgraduate thesis, Ecological Knowledge Research Group, School of Agricultural and Forest Sciences, University of Wales.

Tulachan, P.M. and A. Neupane. 1999. Livestock in mixed farming systems of Hindu Kush-Himalayas: trends and sustainability. International Center for Integrated Mountain Development (ICIMOD), Kathmandu, Nepal. 